\title{
PENGARUH PERSEPSI PELAKSANAAN SENSUS PAJAK NASIONAL, PENGETAHUAN PERATURAN PERPAJAKAN, DAN KESADARAN PERPAJAKAN TERHADAP KEPATUHAN WAJIB PAJAK DI DAERAH ISTIMEWA YOGYAKARTA
}

\author{
Ana Choirun Nisa'* \\ Andri Wakita Aji \\ Program Studi Akuntansi Fakultas Ekonomi \\ Universitas Sarjanawiyata Tamansiswa \\ *Q_Anacn@yahoo.com
}

\begin{abstract}
This research is aimed to know the influence of perception of Sensus Pajak Nasional, knowledge of taxation laws, tax awareness to tax compliance in the Special Region of Yogyakarta. This research uses purposive sampling and survey methods with questionnaires. Questionnaires distributions to 100 respondents. The respondents of this research are taxpayer'sespecially business owners who are in the business districtand have stickers of Sensus Pajak Nasional. Data analysis was performed using multiple linear regression analysis with SPSS 19 for windows.

The results of this research indicated that perception of Sensus Pajak Nasional have a positive and significant influence on taxpayer's compliance. knowledge of taxation laws have a positive and significant influence on taxpayer's compliance, and tax awareness have a positive and significant influence on taxpayer's compliance. The magnitude of perception of Sensus Pajak Nasional, knowledge of taxation laws, tax awareness to tax compliance to explain tax compliance is $83,3 \%$, while the remaining $16,7 \%$ explained by other variables not examined in this research.
\end{abstract}

Keyword: the perception of Sensus Pajak Nasional, knowledge of taxation laws, tax

\section{PENDAHULUAN}

Pajak merupakan sumber utama penerimaan Negara.Tanpa pajak, sebagian besar kegiatan Negara sulit untuk dilaksanakan. Pembangunan jalan-jalan, jembatan, sekolah, rumah sakit atau puskesmas, kantor polisi, dan fasilitas umum lainnya dibiayai menggunakan uang yang berasal dari pajak.

Besarnya penerimaan pajak tergantung pada kepatuhan wajib pajak.Tingkat kepatuhan Wajib pajak di Indonesia masih sangatlah rendah. Hal ini dibuktikan dengan masih rendahnya tax ratio yaitu $12,3 \%$ pada tahun 2012 (LensaIndonesia.com). Tax ratio menurut Dewinta dan Muchamad (2012) adalah perbandingan antara jumlah penerimaan pajak dibandingkan dengan
Produk Domestik Bruto (PDB) suatu Negara. Rasio ini dipergunakan untuk menilai tingkat kepatuhan pembayaran pajak oleh masyarakat dalam suatu Negara.

Kesadaran masyarakat akan kewajibannya dalam membayar pajak akan mempengaruhi tingkat kepatuhan. Kesadaran masyarakat yang tinggi akan mendorong semakin banyak masyarakat memenuhi kewajibannya untuk mendaftarkan diri sebagai Wajib Pajak, melaporkan dan membayar pajaknya dengan benar sebagai wujud tanggung jawab berbangsa dan bernegara.

Pengetahuan peraturan perpajakan juga penting dalam meningkatkan kepatuhan wajib pajak.Karena pengetahuan peraturan perpajakan merupakan hal yang paling 
mendasar yang harus dimiliki oleh wajib pajak untuk memenuhi kewajiban perpajakanya.

Untuk meningkatkan kepatuhan wajib pajak Direktorat Jenderal (Ditjen) Pajak juga melaksanakan kegiatan Sensus Pajak Nasional (SPN).SPN adalah kegiatan pengumpulan data mengenai kewajiban perpajakan untuk memperluas basis pajak dengan mendatangi langsung subjek pajak. Keberhasilan SPN tidak lepas dari Persepsi yang positif atas pelaksanaan SPN. Persepsi yang positif akan menumbuhkan kepatuhan sukarela.Persepsi yang positif terhadap SPN,pengetahuan peraturan perpajakan, dankesadaran perpajakan masyarakat akan mendorong kepatuhan sukarela.

Beberapa penelitian tentang kepatuhan Wajib Pajak telah dilakukan oleh penelitipeneliti terdahulu.Asih (2009) melakukan penelitian mengenai pengaruh pengetahuan tentang pajak, persepsi tentang petugas pajak, dan penerapan sistem administrasi perpajakan modern terhadap kepatuhan Wajib Pajak badan di Kantor Pelayanan Pajak Surabaya.Hasil penelitian Asih (2009) adalah bahwa pengetahuan tentang pajak dan penerapan sistem administrasi perpajakan modern memiliki pengaruh terhadap kepatuhan Wajib Pajak, sedangkan variabel persepsi tentang petugas pajak tidak berpengaruh terhadap kepatuhan Wajib Pajak.

Rajif (2010) melakukan penelitian tentang hubungan pemahaman, kualitas pelayanan, dan ketegasan sanksi perpajakan terhadap kepatuhan Wajib Pajak pengusaha Usaha Kecil dan Menengah di daerah Cirebon. Hasil penelitian menunjukkan bahwa variabel pemahaman, kualitas pelayanan, dan ketegasan sanksi perpajakan memiliki perngaruh yang positif signifikan terhadap kepatuhan Wajib Pajak baik secara parsial maupun simultan.

Irawan et al (2012) melakukan penelitian terhadap Wajib Pajak orang pribadi di KPP Pratama Senapelan Pekanbaru. Variabel independen dalam penelitian ini yaitu pengetahuan Wajib Pajak tentang peraturan perpajakan, penyelewengan pajak, dan persepsi Wajib Pajak atas kinerja pelayanan perpajakan sedangkan variabel dependennya yaitu motivasi Wajib Pajak dalam memenuhi kewajiban perpajakan. Hasil penelitian menunjukkan bahwa ketiga variabel independen yaitu pengetahuan Wajib Pajak tentang peraturan perpajakan, penyelewengan pajak, dan persepsi Wajib Pajak atas kinerja pelayanan perpajakan memiliki pengaruh yang signifikan positif baik secara parsial maupun simultan terhadap motivasi Wajib Pajak dalam memenuhi kewajiban perpajakan.

Penelitian yang dilakukan oleh Musyarofah dan Adi (2008) menguji pengaruh kesadaran, persepsi tentang sanksi dan hasrat membayar pajak terhadap kepatuhan Wajib Pajak di KPP Gubeng Surabaya.Hasil penelitian menunjukkan bahwa variabel kesadaran Wajib Pajak dan persepsi tentang sanksi memiliki perngaruh yang signifikan terhadap kepatuhan Wajib Pajak sedangkan variabel hasrat membayar pajak tidak berpengaruh terhadap kepatuhan Wajib Pajak.

Dewinta dan Muchamad (2012) melakukan penelitian tentang pengaruh persepsi pelaksanaan Sensus Pajak Nasional dan kesadaran perpajakan terhadap kepatuhan Wajib Pajak orang pribadi maupun badan di lingkungan Kantor Wilayah Direktorat Jenderal Pajak Daerah Istimewa Yogyakarta. Hasil penelitian yang dilakukan oleh Dewinta dan Muchamad (2012) yaitu bahwa variabel persepsi pelaksanaan Sensus Pajak Nasional dan kesadaran perpajakan memiliki pengaruh yang signifikan positif terhadap kepatuhan Wajib Pajak.

Penelitian ini mengacu pada penelitian Dewinta dan Muchamad (2012) yang menguji pengaruh persepsi pelaksanaan Sensus Pajak Nasional dan kesadaran perpajakan terhadap kepatuhan Wajib Pajak orang pribadi maupun badan di lingkungan Kantor Wilayah Direktorat Jenderal Pajak Daerah Istimewa Yogyakarta. Namun, pada penelitian ini peneliti menambah satu variabel independen yaitu pengetahuan peraturan perpajakan, 
karena menurut Utami et al (2012) ketika tingkat pengetahuan dan pemahaman akan peraturan pajak meningkat, hal ini akan mendorong Wajib Pajak untuk melakukan kewajiban membayar pajak. Begitu juga menurut Nugroho (2012) semakin tinggi pengetahuan dan pemahaman Wajib Pajak, maka Wajib Pajak dapat menentukan perilakunya dengan lebih baik dan sesuai dengan ketentuan perpajakan. Namun jika Wajib Pajak tidak memiliki pengetahuan mengenai peraturan dan proses perpajakan, maka Wajib Pajak tidak dapat menentukan perilakunya dengan tepat.

Rumusan masalah dalam penelitian ini adalah " Apakah persepsi pelaksanaan Sensus Pajak Nasional, pengetahuan peraturan perpajakan, dan kesadaran perpajakan berpengaruh terhadap kepatuhan Wajib Pajak di Daerah Istimewa

\section{KAJIAN TEORI}

Persepsi merupakan penilaian seseorang terhadap suatu hal yang dapat dipengaruhi oleh pengalaman dan proses belajar individu. Sensus Pajak Nasional (SPN) adalah kegiatan pengumpulan data data mengenai kewajiban perpajakan untuk memperluas basis pajak dengan mendatangi langsung subjek pajak. Data yang dihasilkan dari SPN yaitu berupa data tentang subjek sensus, lokasi sensus, dan kondisi subjek sensus, data-data tersebut kemudian akan diolah menjadi suatu informasi bagi Direktorat Jenderal (Ditjen) pajak untuk menilai kepatuhan wajib pajak. Jika persepsi wajib pajak terhadap Sensus Pajak Nasional positif maka dapa mempengaruhi perilaku mereka dalam menghitung, menyetor, dan melaporkan pajak terutangnya secara benar dan tepat waktu.

Pengetahuan adalah hasil kerja fikir yang merubah dari tidak tahu menjadi tahu dan menghilangkan keraguan terhadap suatu perkara. Menurut prasanti (2012) pengetahuan peraturan perpajakan adalah proses atau cara wajib pajak memahami peraturan perpajakan yang telah ada serta perubahan sikap dan tata laku seorang wajib pajak atau kelompok wajib pajak dalam usaha mendewasakan manusia dalam upaya pengajaran dan latihan.

Kesadaran adalah keadaan seseorang di mana ia tahu atau mengerti dengan jelas apa yang ada dalam pikirannya. Muliari (2011) kesadaran perpajakan adalah suatu kondisi dimana seseorang mengetahui, mengakui, menghargai dan menaati ketentuan perpajakan yang berlaku serta memiliki kesungguhan dan kenginan untuk memenuhi kewajiban perpajakannya. Kesadaran masyarakat akan kewajibannya dalam membayar pajak akan mempengaruhi tingkat kepatuhan sukarela.

\section{PERUMUSAN HIPOTESIS}

\section{Pengaruh Persepsi Pelaksanaan Sensus} Pajak Nasional Terhadap Kepatuhan Wajib Pajak

Rendahnya kepatuhan Wajib Pajak disebabkan oleh banyak hal, tetapi yang paling utama menurut Alm, Bahl, Murray (1990) dalam John Hutagaol (2007) adalah disebabkan oleh tidak adanya data tentang Wajib Pajak yang dapat digunakan untuk mengetahui kepatuhannya. Persepsi yang positif atas suatu sistem perpajakan memiliki pengaruh terhadap kepatuhan Wajib Pajak. Begitu juga dengan pelaksanaan Sensus Pajak Nasional, jika persepsi Wajib Pajak terhadap Sensus Pajak Nasional positif maka dapat memengaruhi perilaku mereka dalam menghitung, menyetor, dan melaporkan pajak terutangnya secara benar dan tepat waktu.

H1 : Persepsi Pelaksanaan Sensus Pajak Nasional berpengaruh signifikan positif terhadap kepatuhan Wajib Pajak

\section{Pengaruh Pengetahuan Peraturan Perpajakan Terhadap Kepatuhan Wajib Pajak}

Menurut Gardina dan Haryanto (2006) dalam Mulya (2012) salah satu penyebab berpengaruhnya pengetahuan pajak terhadap kepatuhan pajak adalah adanya sumber informasi perpajakan yang didapat oleh setiap Wajib Pajak.Wajib Pajak yang tidak memahami peraturan perpajakan secara jelas 
cenderung akan menjadi Wajib Pajak yang tidak taat, dan sebaliknya semakin paham Wajib Pajak terhadap peraturan perpajakan, maka semakin paham pula Wajib Pajak terhadap sanksi yang akan diterima bila melalaikan kewajiban perpajakannya.

H2 : Pengetahuan Peraturan Perpajakan berpengaruh signifikan positif terhadap kepatuhan Wajib Pajak

\section{Pengaruh Kesadaran Perpajakan \\ Terhadap KepatuhanWajib Pajak}

Muliari (2011) kesadaran perpajakan adalah suatu kondisi dimana seseorang mengetahui, mengakui, menghargai dan menaati ketentuan perpajakan yang berlaku serta memiliki kesungguhan dan kenginan untuk memenuhi kewajiban perpajakannya.Muliari (2011), menyatakan bahwa semakin tinggi tingkat kesadaran Wajib Pajak maka pemahaman dan pelaksanaan kewajiban perpajakan semakin baik sehingga dapat meningkatkan kepatuhan. H3 : Kesadaran perpajakan berpengaruh signifikan positif terhadap kepatuhan Wajib Pajak

Pengaruh persepsi pelaksanaan Sensus Pajak Nasional, pengetahuan peraturan perpajakan, dan kesadaran perpajakan terhadap kepatuhan Wajib Pajak

Kepatuhan dari aspek psikologis melihat bagaimana persepsi Wajib Pajak akan suatu sistem perpajakan dalam hal ini adalah Sensus Pajak Nasional. Jika persepsi masyarakat positif terhadap pelaksanaan Sensus Pajak Nasional maka akan mempengaruhi perilaku mereka dalam memenuhi kewajiban perpajakannya.

Wajib Pajak yang memiliki pengetahuan tentang peraturan perpajakan akan melaksanakan kewajiban perpajakannya sesuai dengan peraturan perpajakan yang berlaku. Dengan adanya pengetahuan peraturan perpajakan tersebut akan membantu wajib pajak dalam membayar pajak, sehingga tingkat kepatuhan akan meningkat.

Kesadaran perpajakan sangat penting dalam meningkatkan kepatuhan Wajib Pajak.
Ketika Wajib Pajak memiliki kesadaran maka membayar pajak akan dilakukan secara sukarela bukan keterpaksaan dan akan meningkatkan kepatuhan Wajib Pajak.

Berdasarkan hal tersebut maka dirumuskan hipotesis sebagai berikut:

H4 : Persepsi pelaksanaan Sensus Pajak Nasional, pengetahuan peraturan perpajakan, dan kesadaran perpajakan berpengaruh signifikan positif terhadap kepatuhan Wajib Pajak

\section{METODE PENELITIAN}

\section{Sifat penelitian}

Penelitian ini adalah penelitian deskriptif kuantitatif.Menurut Neuman (2003) dalam Efferinet al (2008) pendekatan kuantitatif berangkat dari penggunaan datadata yang terukur secara tepat yang diperoleh melalui survey atau kuesioner dan dikombinasikan dengan statistik dan pengujian hipotesis yang bebas nilai atau objektif. Dengan cara itu maka suatu fenomena dapat dianalisis untuk kemudian dijelaskan hubungan diantara variabelvariabel yang terlibat di dalamnya.

\section{Populasi, Sampel, dan Teknik Pengambilan Sampel}

Populasi dalam penelitian ini adalah Wajib Pajak Orang Pribadi dan Wajib Pajak Badan yang berada di Daerah Istimewa Yogyakarta. Pengambilan sampel dilakukan dengan metode purposive sampling. Alasan pengambilan sampel dengan menggunakan metode purposive sampling karena hanya akan memilih sampel dengan kriteria tertentu agar jawaban dari para responden sesuai dengan jalannya penelitian. Kriteria sampel dalam penelitian ini yaitu:

1. Wajib Pajak yang berada di sentra-sentra bisnis, kawasan perdagangan, kawasan perindustrian. Karena kawasan tersebut merupakan sasaran prioritas pelaksanaan Sensus Pajak Nasional.

2. Wajib Pajak yang telah memiliki stiker Sensus Pajak Nasional. Stiker ini merupakan tanda bahwa Wajib Pajak telah disensus oleh petugas pajak. 


\section{Sumber Data dan Metode Pengumpulan Data}

Data diperoleh dari jawaban responden atas serangkaian pertanyaan yang diajukan peneliti mengenai persepsi pelaksanaan Sensus Pajak Nasional, pengetahuan peraturan perpajakan, kesadaran perpajakan, dan kepatuhan Wajib Pajak.

Metode pengumpulan data dalam penelitian ini menggunakan kuesioner.Untuk mengukur pendapat responden digunakan skala 4 angka yaitu angka 4 untuk pendapat sangat setuju dan angka 1 untuk pendapat sangat tidak setuju. Perinciannya adalah sebagai berikut:

Angka 1 = Sangat Tidak Setuju

Angka 2 = Tidak Setuju

Angka 3 = Setuju

Angka 4 = Sangat Setuju

\section{Model Regresi}

Analisis yang digunakan dalam penelitian ini adalah analisis regresi linier berganda.Model regresi linier berganda dirumuskan sebagai berikut:

$\mathrm{Y}=\alpha+\beta_{1} \mathrm{X}_{1}+\beta_{2} \mathrm{X}_{2}+\beta_{3} \mathrm{X}_{3}+\mathrm{e}$

Keterangan:

$\mathrm{Y}=$ Kepatuhan Wajib Pajak

$\alpha=$ Konstanta

$\beta_{1}=$ Koefisien regresi persepsi pelaksanaan Sensus Pajak Nasional

\section{HASIL PENELITIAN DAN \\ PEMBAHASAN \\ Deskripsi Objek Penelitian}

Jumlah kuesioner yang disebar dalam penelitian ini adalah sebanyak 100
$2=$ Koefisien regresi pengetahuan peraturan perpajakan

$3_{3}=$ Koefisien regresi kesadaran perpajakan

$\mathrm{X}_{1}=$ Persepsi pelaksanaan Sensus Pajak Nasional

$\mathrm{X}_{2}=$ Pengetahuan peraturan perpajakan

$\mathrm{X}_{3}=$ Kesadaran perpajakan

$\mathrm{e}=$ Kesalahan pengganggu

\section{Analisis Regresi}

Pengujian yang dilakukan dalam analisis regresi linier berganda dalam penelitian ini adalah sebagai berikut :

a. Koefisien determinasi $\left(\mathrm{R}^{2}\right)$

Koefisien determinasi digunakan untuk mengukur seberapa besar variabel independen dapat menjelaskan variabel dependen.

b. Uji Signifikansi paramater individual (Uji t)

Uji parsial digunakan untuk mengetahui pengaruh masing-masing variabel independen terhadap variabel dependen.

c. Uji Signifikansi Parameter Simultan (Uji F)

Menurut Widarjono (22:2010) pengujian $\mathrm{F}$ digunakan untuk mengevaluasi pengaruh semua variabel independen terhadap variabel dependen.

kuesioner.Data responden yang berhasil dikumpulkan sebanyak 97 kuesioner, sehingga jumlah sampel pengamatan sebanyak 97 pengamatan yang dapat dilihat pada tabel 1:

Tabel 1

Deskripsi Objek Penelitian

\begin{tabular}{lc}
\hline & Jumlah Kuesioner \\
\hline Jumlah Kuesioner yang disebar & 100 \\
Dikurangi: & \\
Kuesioner yang tidak kembali & $(3)$ \\
\hline Sampel akhir pengamatan & 97 \\
\hline
\end{tabular}

Sumber: Data primer diolah, 2013

Sampel tersebut kemudian diklasifikasikan berdasarkan jenis Wajib Pajak, lama berdirinya usaha, lama memiliki Nomor Pokok Wajib Pajak (NPWP), jenis usaha, 


\section{JURNAL AKUNTANSI. VOL.2 NO.1 JUNI 2014}

dan pengetahuan perpajakan sebagaimana dapat dilihat pada tabel-tabel berikut ini:

Tabel 2

Tabulasi Silang Jenis Usaha dan Jenis Wajib Pajak

\begin{tabular}{|c|c|c|c|}
\hline \multirow{2}{*}{ Jenis Usaha } & \multicolumn{2}{|c|}{ Jenis Wajib Pajak } & \multirow{2}{*}{ Total } \\
\hline & Orang Pribadi & Badan & \\
\hline \multirow[t]{2}{*}{ Industri } & 0 & 11 & 11 \\
\hline & $0 \%$ & $11,3 \%$ & $11,3 \%$ \\
\hline \multirow[t]{2}{*}{ Jasa } & 25 & 13 & 38 \\
\hline & $25,8 \%$ & $13,4 \%$ & $56,7 \%$ \\
\hline \multirow[t]{2}{*}{ Dagang } & 33 & 15 & 48 \\
\hline & $34,0 \%$ & $15,5 \%$ & $49,5 \%$ \\
\hline \multirow[t]{2}{*}{ Lainnya } & 0 & 0 & 0 \\
\hline & $0 \%$ & $0 \%$ & $0 \%$ \\
\hline \multirow[t]{2}{*}{ TOTAL } & 58 & 39 & 97 \\
\hline & $59,8 \%$ & $40,2 \%$ & $100 \%$ \\
\hline
\end{tabular}

Sumber: Data primer diolah, 2013

Berdasarkan Tabel 2 di atas dapat diketahui bahwa 59,8\% responden adalah Wajib Pajak Orang Pribadi sedangkan 40,2\% adalah Wajib Pajak Badan. Jenis usaha yang paling banyak untuk Wajib
Pajak Orang Pribadi adalah dagang dengan prosentase 34\% sedangkan jenis usaha yang paling banyak untuk Wajib Pajak Badan adalah dagang dengan prosentase $15,5 \%$.

Tabel 3

Tabulasi Silang Lama Berdirinya Usaha dan Jenis Wajib Pajak

\begin{tabular}{cccc}
\hline $\begin{array}{c}\text { Lama } \\
\text { Berdirinya } \\
\text { Usaha }\end{array}$ & \multicolumn{2}{c}{ Jenis Wajib Pajak } & Total \\
Orang Pribadi & Badan & \\
\hline$<5$ Tahun & 5 & 9 & 14 \\
& $5,2 \%$ & $9,3 \%$ & $14,4 \%$ \\
5-10 Tahun & 25 & 19 & 44 \\
& $25,8 \%$ & $19,6 \%$ & $45,4 \%$ \\
10-20 Tahun & 28 & 11 & 39 \\
& $28,9 \%$ & $11,3 \%$ & $40,2 \%$ \\
$>20$ Tahun & 0 & 0 & 0 \\
& $0,0 \%$ & $0 \%$ & $0,0 \%$ \\
\hline TOTAL & 58 & 39 & 97 \\
& $59,8 \%$ & $40,2 \%$ & $100 \%$ \\
\hline
\end{tabular}

Sumber: Data primer diolah, 2013

Berdasarkan Tabel 3 di atas dapat dilihat bahwa responden Wajib Pajak Orang Pribadi paling banyak memiliki lama usaha antara 10-20 tahun dengan prosentase $28,9 \%$ sedangkan Wajib Pajak Badan paling banyak memiliki lama usaha antara 5-10 tahun dengan prosentase $19,6 \%$. 


\section{Tabel 4}

Tabulasi Silang Lama Memiliki NPWP dan Jenis Wajib Pajak

\begin{tabular}{|c|c|c|c|}
\hline \multirow{2}{*}{$\begin{array}{c}\text { Lama } \\
\text { Memiliki } \\
\text { NPWP }\end{array}$} & \multicolumn{2}{|c|}{ Jenis Wajib Pajak } & \multirow[t]{2}{*}{ Total } \\
\hline & Orang Pribadi & Badan & \\
\hline$<5$ Tahun & $\begin{array}{c}5 \\
5,2 \%\end{array}$ & $\begin{array}{c}9 \\
9,3 \%\end{array}$ & $\begin{array}{c}14 \\
14,4 \%\end{array}$ \\
\hline 5-10 Tahun & $\begin{array}{c}31 \\
32,0 \%\end{array}$ & $\begin{array}{c}17 \\
17,5 \%\end{array}$ & $\begin{array}{c}48 \\
32,0 \%\end{array}$ \\
\hline 10-20 Tahun & $\begin{array}{c}22 \\
22,7 \%\end{array}$ & $\begin{array}{c}13 \\
13,4 \%\end{array}$ & $\begin{array}{c}35 \\
36,1 \%\end{array}$ \\
\hline$>20$ Tahun & $\begin{array}{c}0 \\
0 \% \\
\end{array}$ & $\begin{array}{c}0 \\
0 \%\end{array}$ & $\begin{array}{c}0 \\
0,0 \% \\
\end{array}$ \\
\hline TOTAL & $\begin{array}{c}58 \\
59,8 \%\end{array}$ & $\begin{array}{c}39 \\
40,2 \%\end{array}$ & $\begin{array}{c}97 \\
100 \%\end{array}$ \\
\hline
\end{tabular}

Sumber: Data primer diolah, 2013

Dari Tabel 4dapat diketahui bahwa dengan prosentanse 32\% sedangkan Wajib responden Wajib Pajak Orang Pribadi paling Pajak Badan paling banyak memiliki NPWP banyak memliki NPWP antara 5-10 tahun antara 5-10 tahun dengan prosentase 17,5\%.

\section{Tabel 5}

Tabulasi Silang Pengetahuan Perpajakan dan Jenis Wajib Pajak

\begin{tabular}{|c|c|c|c|}
\hline \multirow{2}{*}{$\begin{array}{c}\text { Pengetahuan } \\
\text { Perpajakan }\end{array}$} & \multicolumn{2}{|c|}{ Jenis Wajib Pajak } & \multirow{2}{*}{ Total } \\
\hline & Orang Pribadi & Badan & \\
\hline Belajar & 13 & 8 & 21 \\
\hline Sendiri & $13 \%$ & $8,2 \%$ & $13 \%$ \\
\hline \multirow[t]{2}{*}{ Kursus } & 5 & 3 & 8 \\
\hline & $5,2 \%$ & $3,1 \%$ & $5,2 \%$ \\
\hline \multirow[t]{2}{*}{ Penyuluhan } & 21 & 17 & 38 \\
\hline & $21,6 \%$ & $17,5 \%$ & $21,6 \%$ \\
\hline \multirow[t]{2}{*}{ Pelatihan } & 19 & 11 & 30 \\
\hline & $19,6 \%$ & $11,3 \%$ & $19,6 \%$ \\
\hline \multirow[t]{2}{*}{ TOTAL } & 58 & 39 & 97 \\
\hline & $59,8 \%$ & $40,2 \%$ & $100 \%$ \\
\hline
\end{tabular}

Sumber: Data primer diolah, 2013

Dari Tabel 5 di atas dapat diketahui bahwa Wajib Pajak Orang Pribadi paling banyak mendapat pengetahuan perpajakan dari penyuluhan dengan prosentase $21,6 \%$ sedangkan Wajib Pajak Badan paling banyak mendapat pengetahuan perpajakan dari penyuluhan dengan prosentase $17,5 \%$. 


\section{Analisis Data}

\section{Statistik Deskriptif}

\begin{tabular}{cccccc}
\hline & & & & & Std. \\
& N & \multicolumn{1}{c}{ Minimum Maximum } & Mean & Deviation \\
\hline Y & 97 & 20.00 & 32.00 & 26.5052 & 3.29179 \\
X1 & 97 & 21.00 & 36.00 & 30.2990 & 3.59735 \\
X2 & 97 & 10.00 & 26.00 & 21.4845 & 3.29492 \\
X3 & 97 & 20.00 & 36.00 & 29.3608 & 3.77819 \\
\hline Valid N & 97 & & & & \\
(listwise) & & & & & \\
\hline
\end{tabular}

Sumber : Data Primer Diolah, 2013

Berdasarkan Tabel 6 di atas dapat diketahui nilai rata-rata untuk variabel kepatuhan Wajib Pajak sebesar 26,51, variabel persepsi pelaksanaan Sensus Pajak Nasional memiliki nilai rata-rata sebesar 30,30, variabel pengetahuan peratuan perpajakan memiliki nilai rata-rata sebesar 21,48, dan variabel kesadaran perpajakan
Std.

Tabel 6

Statistik Deskriptif Variabel Penelitian Descriptive Statistics

memiliki nilai rata-rata sebesar 29,36. Hal ini menunjukkan bahwa sebagian besar responden menjawab setuju atas pertanyaanpertanyaan yangberkaitan dengan kepatuhan Wajib Pajak, persepsi pelaksanaan Sensus Pajak Nasional, pengetahuan peratuan perpajakan, dan kesadaran perpajakan.

\section{Analisis Regresi}

Hasil analisis regresi berganda dapat dilihat pada tabel 7 berikut ini:

Tabel 7

Hasil Uji Regresi Linier Berganda

Coefficients $^{\mathrm{a}}$

\begin{tabular}{|c|c|c|c|c|c|}
\hline \multirow[t]{2}{*}{ Model } & \multicolumn{2}{|c|}{$\begin{array}{c}\text { Unstandardized } \\
\text { Coefficients }\end{array}$} & \multirow{2}{*}{$\begin{array}{c}\begin{array}{c}\text { Standardize } \\
\mathrm{d} \\
\text { Coefficients }\end{array} \\
\text { Beta }\end{array}$} & \multirow[t]{2}{*}{$\mathrm{t}$} & \multirow[t]{2}{*}{ Sig. } \\
\hline & B & Std. Error & & & \\
\hline $\begin{array}{l}1 \text { ((Consta } \\
\mathrm{nt})\end{array}$ & 2.410 & 1.165 & & 2.069 & .041 \\
\hline $\mathrm{X} 1$ & .240 & .098 & .263 & 2.456 & .016 \\
\hline $\mathrm{X} 2$ & .343 & .070 & .344 & 4.880 & .000 \\
\hline $\mathrm{X} 3$ & .321 & .088 & .369 & 3.652 & .000 \\
\hline
\end{tabular}

a. Dependent Variable:Y

Sumber : Data Primer Diolah, 2013

Berdasarkan tabel 7 diatas dapat ditulis persamaan regresi dari penelitian ini adalah sebagai berikut:

$\mathrm{Y}=\mathbf{2 . 4 1 0}+0.240 \mathrm{X} 1+0.343 \mathrm{X} 2+0.321 \mathrm{X} 3+\mathrm{e}$ 


\section{Pengujian Hipotesis}

\section{Koefisien Determinasi}

Nilai Adjusted $R$ Square dari model regersi diperoleh sebesar 0.833, hal ini berarti sebesar 83,3\% kepatuhan Wajib Pajak dijelaskan oleh persepsi pelaksanaan Sensus
Pajak Nasional, pengetahuan peraturan perpajakan, dan kesadaran perpajakan, sedangkan sisanya sebesar $16,7 \%$ merupakan variabel-variabel lain yang tidak dijelaskan dalam penelitian ini.Tabel koefisien determinasi adalah sebagai berikut:

Tabel 8

Koefisien Determinasi Model Summary

\begin{tabular}{lrrrr}
\hline Model & $\mathrm{R}$ & R Square & $\begin{array}{c}\text { Adjusted R } \\
\text { Square }\end{array}$ & $\begin{array}{l}\text { Std. Error of } \\
\text { the Estimate }\end{array}$ \\
\hline 1 & $.916^{\mathrm{a}}$ & .839 & .833 & 1.34349 \\
\hline a. Predictors: (Constant), X3, X2, X1 & &
\end{tabular}

Sumber : Data Primer Diolah, 2013

\section{Uji Signifikansi Paramater Individual (Uji t)}

Hasil uji signifikansi parameter individual dapat dilihat pada tabel 4.17 berikut ini:

Tabel 9

Hasil Uji Signifikansi Paramater Individual (Uji t)

\begin{tabular}{|c|c|c|c|c|c|c|}
\hline & & & Coefficient & & & \\
\hline & Model & $\begin{array}{r}\text { Unstan } \\
\text { Coeff }\end{array}$ & $\begin{array}{l}\text { dardized } \\
\text { icients }\end{array}$ & $\begin{array}{l}\text { Standardize } \\
\mathrm{d} \\
\text { Coefficients }\end{array}$ & $\mathrm{t}$ & Sig. \\
\hline & & B & Std. Error & Beta & & \\
\hline 1 & $\begin{array}{l}\text { ((Constan } \\
\text { t) }\end{array}$ & 2.410 & 1.165 & & 2.069 & .041 \\
\hline & $\mathrm{X} 1$ & .240 & .098 & .263 & 2.456 & .016 \\
\hline & $\mathrm{X} 2$ & .343 & .070 & .344 & 4.880 & .000 \\
\hline & $\mathrm{X} 3$ & .321 & .088 & .369 & 3.652 & .000 \\
\hline
\end{tabular}

Sumber : Data Primer Diolah, 2013

Dari tabel 9 diatas dapat dilihat bahwa variabel persepsi pelaksanan Sensus Pajak Nasional (X1) memiliki nilai t hitung sebesar 2.456 , berarti t hitung $>\mathrm{t}$ tabel $(2.456>1,986)$ sedangkan tingkat signifikansi sebesar 0,016 karena tingkat signifikansi $<0.05$ maka $\mathrm{H} 0$ ditolak dan Ha diterima.Hal ini menunjukkan bahwa variabel persepsi pelaksanaan Sensus Pajak Nasional memiliki pengaruh yang positif signifikan terhadap kepatuhan Wajib
Pajak. Artinya semakin tinggi atau baik persepsi Wajib Pajak atas pelaksanaan Sensus Pajak Nasional maka akan meningkatkan tingkat kepatuhan Wajib Pajak begitu pula sebaliknya.Penemuan ini mendukung penemuan Dewinta dan Muchamad (2012) yang menyatakan bahwa persepsi pelaksanaan Sensus Pajak Nasional berpengaruh signifikan positif terhadap kepatuhan Wajib Pajak. 
Hasil pengujian untuk variabel pengetahuan peraturan perpajakan (X2) terhadap kepatuhan Wajib Pajak adalah sebesar 4,880. Karena t hitung lebih besar dari $t$ tabel $(4,880>1,986)$ serta memiliki tingkat signifikansi kurang dari 0,05 $(0.000$ $<0,05)$ maka H0 ditolak dan menerima Ha. Artinya dengan tingkat kepercayaan 95\% dapat disimpulkan bahwa variabel pengetahuan peraturan perpajakan memiliki pengaruh yang positif signifikan terhadap kepatuhan Wajib Pajak.Hal tersebut mendukung penelitian yang dilakukan oleh Siregar et al (2012), Asih (2009), dan Septianti (2012). Semakin tinggi tingkat pengetahuan peraturan perpajakan Wajib Pajak maka akan meningkatkan tingkat kepatuhan Wajib Pajak begitu pula sebaliknya semakin rendah tingkat pengetahuan peraturan perpajakan Wajib Pajak maka akan menurunkan tingkat kepatuhan Wajib Pajak.

\section{Uji Signifikansi Paramater Simultan (Uji F)}

Hasil uji statistik secara simultan untuk persepsi pelaksanaan Sensus Pajak Nasional
Berdasarkan Tabel 4.17 nilai t hitung untuk variabel kesadaran perpajakan (X3) adalah sebesar 3.652. Karena nilai t hitung lebih besar dari $t$ tabel $(3,652>1,986)$ dan tingkat signifikansi kurang dari 0,05 $(0.000<0,05)$ maka $\mathrm{H} 0$ ditolak dan menerima Ha. Artinya dengan tingkat kepercayaan $95 \%$ dapat disimpulkan bahwa variabel kesadaran perpajakan memiliki pengaruh yang signifikansi positif terhadap kepatuhan Wajib Pajak di Daerah Istimewa Yogyakarta.Hal tersebut mendukung penemuan Dewinta dan Muchamad (2012), Muliari (2011), dan Arum dan Zulaikha (2012). Semakin tinggi tingkat kesadaran perpajakan Wajib Pajak maka akan meningkatkan tingkat kepatuhan Wajib Pajak begitu pula sebaliknya semakin rendah tingkat kesadaran perpajakan Wajib Pajak maka akan menurunkan tingkat kepatuhan Wajib Pajak.

(X1), pengetahuan peraturan perpjakan (X2), dan kesadaran perpajakan (X3) dapat dilihat pada Tabel 10 berikut ini:

Tabel 10

Hasil Uji Signifikansi Paramater Simultan (Uji F) ANOVA $^{b}$

\begin{tabular}{|c|c|c|c|c|c|c|}
\hline & Model & $\begin{array}{l}\text { Sum of } \\
\text { Squares }\end{array}$ & Df & $\begin{array}{l}\text { Mean } \\
\text { Square }\end{array}$ & $\mathrm{F}$ & Sig. \\
\hline \multirow[t]{3}{*}{1} & $\begin{array}{l}\text { Regressi } \\
\text { on }\end{array}$ & 872.384 & 3 & 290.79 & 161.107 & $.000^{\mathrm{a}}$ \\
\hline & Residual & 167.863 & 93 & 1.80 & & \\
\hline & Total & 1040.247 & 96 & & & \\
\hline
\end{tabular}

a. Predictors: (Constant), X3, X2, X1

b. Dependent Variable: Y

Sumber : Data Primer Diolah, 2013

Berdasarkan hasil uji statistik di atas dapat dijelaskan sebagai berikut:

Diperoleh hasil $\mathrm{F}$ hitung sebesar 161,107 dengan alpha sebesar $5 \%$. F tabel $=2,70$ Sehingga $F$ hitung $>F$ tabel $(161,107>2,70)$. Diperoleh nilai signifikansi sebesar 0.000 yang berarti $<0.05$.Hal ini menunjukkan bahwa variabel persepsi pelaksanaan Sensus Pajak Nasional, pengetahuan peraturan perpajakan, dan kesadaran perpajakan secara simultan berpengaruh terhadap kepatuhan Wajib Pajak di Daerah Istimewa Yogyakarta. 


\section{SIMPULAN}

Berdasarkan hasil penelitian dan pembahasan mengenai pengaruh persepsi pelaksanaan Sensus Pajak Nasional, pengetahuan peraturan perpajakan, dan kesadaran perpajakan terhadap kepatuhan Wajib Pajak, maka pada bagian akhir dari penelitian ini penulis menarik kesimpulan sebagai berikut:

1. Hasil pengujian hipotesis pertama menunjukkan bahwa persepsi pelaksanaan Sensus Pajak Nasional memiliki hubungan yang positif signifikan dengan kepatuhan Wajib Pajak di Daerah Istimewa Yogyakarta. Hal ini menunjukkan bahwa semakin tinggi atau baik persepsi Wajib Pajak atas pelaksanaan Sensus Pajak Nasional maka semakin tinggi tingkat kepatuhan Wajib Pajak di Daerah Istimewa Yogyakarta.

2. Hasil pengujian hipotesis kedua menunjukkan bahwa pengetahuan peraturan perpajakan berpengaruh positif signifikan terhadap kepatuhan Wajib Pajak. Masalah yang terjadi pada Wajib Pajak saat ini yaitu ketidakmengertian mereka atas kewajiban perpajakan yang harus mereka penuhi. Semakin tinggi tingkat pengetahuan peraturan perpajakan Wajib Pajak maka semakin tinggi pula tingkat kepatuhan Wajib Pajak karena Wajib Pajak telah mengetahui kewajiban perpajakan yang harus mereka penuhi.

3. Hasil pengujian hipotesis ketigamenunjukkan bahwa kesadaran perpajakan berpengaruh positif signifikan terhadap kepatuhan Wajib Pajak. Hal ini berarti semakin tinggi tingkat kesadaran perpajakan Wajib Pajak maka semakin tinggi pula tingkat kepatuhan Wajib Pajak. Kesadaran masyarakat yang tinggi akan pentingnya pajak akan mendorong kepatuhan sukarela. Karena membayar pajak merupakan wujud tanggung jawab dan kepedulian berbangsa dan bernegara.

4. Hasil pengujian hipotesis keempat menunjukkan bahwa persepsi pelaksanaan Sensus Pajak Nasional, pengetahuan peraturan perpajakan, dan kesadaran perpajakan berpengaruh secara simultan terhadap kepatuhan Wajib Pajak di Daerah Istimewa Yogyakarta.

5. Kemampuan persamaan regresi dalam menjelaskan variabel-variabel bebas terhadap variabel terikat sebesar $83,3 \%$ sedangkan $16,7 \%$ dijelaskan oleh variabel-variabel lain di luar penelitian ini. Hal ini berarti tingkat kemampuan variabel-variabel bebas yaitu persepsi pelaksanaan Sensus Pajak Nasional, pengetahuan peraturan perpajakan, dan kesadaran perpajakan tinggi terhadap kepatuhan Wajib Pajak.

Penelitian ini tidak lepas dari keterbatasanketerbatasanyang dapat menyebabkan hasil penelitian menjadi bias. Keterbatasan penelitian ini antara lain:

1. Keterbatasan ketersediaan responden penelitian sehingga peneliti tidak dapat memilih responden yang sesuai dengan harapan peneliti. Misalnya, pertanyaanpertanyaan mengenai pengetahuan peraturan perpajakan yang diberikan kepada responden yang memliki tingkat pendidikan Sekolah Dasar (SD). Jawaban yang diberikan oleh responden tersebut tidak akan optimal jika dibandingkan dengan jawaban dari responden yang memiliki tingkat pendidikan Perguruan Tinggi (PT) .

2. Sikap responden yang menganggap bahwa pajak merupakan sesuatu yang mengancam sehingga kemungkinan responden memberikan jawaban yang tidak mencerminkan keadaan sesungguhnya.

Berdasarkan simpulan dan keterbatasan yang telah dikemukakan, maka peneliti memberikan saran antara lain:

1. Untuk peneliti selanjutnya dapat mengembangkan penelitian dengan menambah variabel penelitian, mengganti variabel penelitian, menggunakan variabel intervening atau menggunakan variabel moderasi.

2. Dalam pelaksanaan Sensus Pajak Nasional di tahun berikutnya diharapkan petugas sensus lebih meningkatkan 
kemampuan dalam berkomunikasi dan pengetahuan peraturan perpajakannya. Agar masyarakat dengan sukarela memberikan informasi yang dibutuhkan dalam Sensus Pajak Nasional.

3. Bagi Direktorat Jenderal (Ditjen) Pajak sebaiknya lebih memperbanyak informasi kepada Wajib Pajak mengenai peraturan perpajakan yang berlaku saat ini melalui berbagai media yang dapat dijangkau dengan mudah. Hal ini bertujuan untuk meningkatkan pengetahuan peraturan perpajakan Wajib Pajak.

4. Bagi Ditjen Pajak sebaiknya lebih memperbanyak sosialisasi pentingnya pajak untuk kemajuan Negara . Hal ini bertujuan untuk meningkatkan kesadaran masyarakat untuk membayar pajak sesuai dengan peraturan yang berlaku.

\section{DAFTAR PUSTAKA}

Arum, Harjanti Puspa.Zulaikha. 2012. Jurnal. Pengaruh Kesadaran Wajib Pajak, Pelayanan Fiskus, dan Sanksi Pajak Terhadap Kepatuhan Wajib Pajak Orang Pribadi Yang Melakukan Pekerjaan Bebas. Diponegoro Jurnal Of Accounting.

Asih, Devi Tri. 2009. Skripsi. Pengaruh Pengetahuan Tentang Pajak Persepsi Tentang Petugas Pajak, dan Penerapan Sistem Administrasi Perpajakan Modern Terhadap Kepatuhan Wajib Pajak. STIE PERBANAS.

Dewinta, Rinta Mulia. Muchamad Syafruddin. 2012. Jurnal. Pengaruh Persepsi Pelaksanaan Sensus Pajak Nasional dan Kesadaran Perpajakan Terhadap Kepatuhan Wajib Pajak di Lingkungan Kantor Wilayah Direktorat Jenderal Pajak Daerah Istimewa Yogyakarta. Diponegoro Jurnal of Accounting.

Efferinet al. 2008.Metode Penelitian Akuntansi. Yogyakarta. Graha Ilmu.

Fikriningrum, Winda Kurnia. Muchamad Syafruddin. 2012. Jurnal. Analisis
Faktor-Faktor Yang Mempengaruhi Wajib Pajak Orang Pribadi Dalam Memenuhi Kewajiban Membayar Pajak. Diponegoro Jurnal Of Accounting.

Hutagaol, John. 2007. Perpajakan: Isu-isu Kontemporer. Yogyakarta: Graha Ilmu.

Irawan, Candra. Azwir Nasir. Rusli. 2012. Jurnal. Pengaruh Pengetahuan Wajib Pajak Tentang Peraturan Perpajakan, Penyelewengan Pajak, dan Persepsi Wajib Pajak Atas Kinerja Pelayanan Perpajakan Terhadap Motivasi Wajib Pajak Dalam Memenuhi Kewajiban Perpajakan. Universitas Riau.

LensaIndonesia.com. DirjenPajak :Kontribusinya.15 Januari 2013.

Muliari, Ni Ketut. Putu Eri Setiawan. 2011. Jurnal. Pengaruh Persepsi Tentang Sanksi Perpajakan dan Kesadaran Wajib Pajak Pada Kepatuhan Pelaporan Wajib di Kantor Pelayanan Pajak Pratama Denpasar Timur.Jurnal Akuntansi \& Bisnis, Volume 6.No.1.

Mulya, Imam. 2012. Skripsi. Pengaruh Pengetahuan Pajak Dan Sanksi Perpajakan Terhadap Kepatuhan Pajak (Survey pada WP Badan di KPP Pratama Cianjur).Elib.unikom.ac.id. Diunduh pada $\mathrm{h}$

2013 pada pukul 14:50 WIB.

Musyarofah, Siti. Adi Purnomo. 2008. Jurnal. Pengaruh Kesadaran, Persepsi Tentang Sanksi dan Hasrat Membayar Pajak Terhadap Kepatuhan Wajib Pajak. Jurnal Akuntansi, Manajemen Bisnis, dan Sektor Publik (JAMBSP) Vol. 5 No. 1 Oktober 2008.

Nugroho, Rahman Adi. 2012. Skripsi. FaktorFaktor Yang Mempengaruhi Kemauan Untuk Membayar Pajak Dengan Kesadaran Membayar Pajak Sebagai Variabel Intervening. Universitas Diponegoro.

Prasanti, Uriyanik Sengko. 2012. Skripsi. Pengaruh Kesadaran dan Pengetahuan Terhadap Kemauan Membayar Pajak Orang Pribadi Untuk Membayar Pajak Penghasilan di Kabupaten Bantul. STIE WIWAHA YOGYAKARTA. 
Rajif, Mohamad. 2012. Jurnal. Pengaruh Pemahaman, Kualitas Pelayanan, dan Ketegasan Sanksi Perpajakan Terhadap Kepatuhan Wajib Pajak Pengusaha Usaha Kecil dan Menengah di daerah Cirebon. Universitas Gunadarma

Rustiyaningsih, Sri. 2011. Jurnal. FaktorFaktor Yang Mempengaruhi Kepatuhan Wajib Pajak.Widya Warta No. 02 Tahun XXXV.

Santoso, Singgih. 2000. Buku Latihan SPSS Statistik Parametik. Jakarta. PT Elex Media Komputindo.

Septianti, Ira Dwi. 2012. Skripsi. Pengaruh Pemeriksaan Pajak dan Pengetahuan Pajak terhadap Kepatuhan Wajib Pajak Badan di Kantor Pajak Pratama Bandung Cicadas. Elib.unikom.ac.id.
Diunduh pada pada pukul 15:05 WIB.

Siregar, Yuli Anita. Drs. Saryadi. Sari Listyorini. 2012. Jurnal. Pengaruh Pelayanan Fiskus dan Pengetahuan Perpajakan Terhadap Kepatuhan Wajib Pajak. Jurnal Ilmu Administrari Bisnis Universitas Diponegoro.

Utami, Sri Rizki. Andi. Ayu Noorida Soerono. 2012. Skripsi. Pengaruh Faktor-Faktor Eksternal Terhadap Tingkat Kepatuhan Wajib Pajak di Lingkungan Kantor Pelayanan Pajak Pratama Serang.Universitas Sultan Agung Tirtayasa.

Widarjono, Agus. 2010. Analisis Statistika Multivariat Terapan 